\title{
RECENT SASKATCHEWAN BANDING OF THE WHITE PELICAN
}

by C. Stuart Houston, 863 University Drive, Saskatoon

The White Pelican (Pelecanus erythrorhynchos) has been banded in num. bers almost equal to those of the Double-crested Cormorant in Saskatchewan, but a lower recovery rate has resulted in only half the number of recoveries. The pelican recoveries of earlier Saskatchewan banders have been previously mapped (Houston, 1967, 1968, 1970), apart from a small number banded at Quill Lake in 1939 by A D. Gresham and A. Haak of Winnipeg.

The accompanying maps show the recoveries of all remaining Saskatchewan banding through 1964, all of it done by the writer. This cutoff date was chosen as 1964 , since the pelican is a relatively long-lived bird, with recoveries received fairly regularly up to about seven years of age. These results are summarized in Table 1 . Xerox copies of original banding schedules of Patrick, and Lyon and McArthur. kindly supplied by the banding office at Patuxent, have allowed the original approximate figures to be corrected.

As previously reported (Houston, 1970) one of Bard's pelicans appears to hold the world longevity record for banded birds of this species. A flightless youing banded 378-00930 near Inperial Beach on July 9, 1948, was found October 12, 1960 at Dry Lake, South Dakota $\left(44^{\circ} 30^{\prime}\right.$ N., $97^{\circ} 00^{\prime}$ W.). The finder, Mr. Andrew Russman of Big Stone City, replied recently to confirm that the bird had been found on the date he had reported it, but added that it had not died of starvation as reported on the computer printout, but was found dead, after having been shot by someone else a day or two earlier-some 12 years and three months after banding.

Two other notable longevity records resulted from banding of young pelicans at Redberry Lake by Lyon and McArthur on July 7, 1937. Band No.
378-037:35 was "taken from a pelican on the banks of the Mississippi River" at Baton Rouge, Louisiana on January 15, 1948 by J. P. Longue; the bird was identifiable and so presumably freshly dead, some 10 years and six months after banding. Band No. 378-10769 was taken from a "dead pelican" by J. G. Grace of Ouachita, Arkansas ( $33^{\circ} 50^{\prime}$ N., $92^{\circ} 40^{\prime}$ W.) and was reported in a letter dated October 6, 1951. This was well over 14 years after banding, but since the date of finding was not given, the longevity aspect of this remains unconfirmed.

Pelicans from Redberry, Quill and Last Mountain lakes and probably those from Dore Lake, appear to follow the same flyway; south and slightly east through the Dakotas to Texas, Louisiana and Arkansas. Many of the pelicans from Old Wives and Crane lakes followed the same course, but a few travelled much farther west to western Montana. Wyoming and Utah. Three of the Crane Lake pelicans, banded by me in company with the late Steve A. Mann, likely took the western pathway, since they wintered along the Pacific shore of Mexico; one of them reached Libertad, El Salvador, the record distance for a Saskatchewan pelican. In fact, it is farther south than any recoveries reported from pelicans banded at Yellowstone Park or Great Salt Lake, though both of these populations typically winter along the western coast of Mexico (Behle, 1958; Diem and Condon, 1967).

Unlike the cormorants, there has been little change in the pelican migration routes over a 35 year period, except that the Redberry Lake pelicans in recent years seem to have dispersed more widely at the northern and southern edges of their range. There have been six recoveries, all of birds more than two years of age, from Alberta. There have been proportionately more recoveries from Mexico, in comparison 


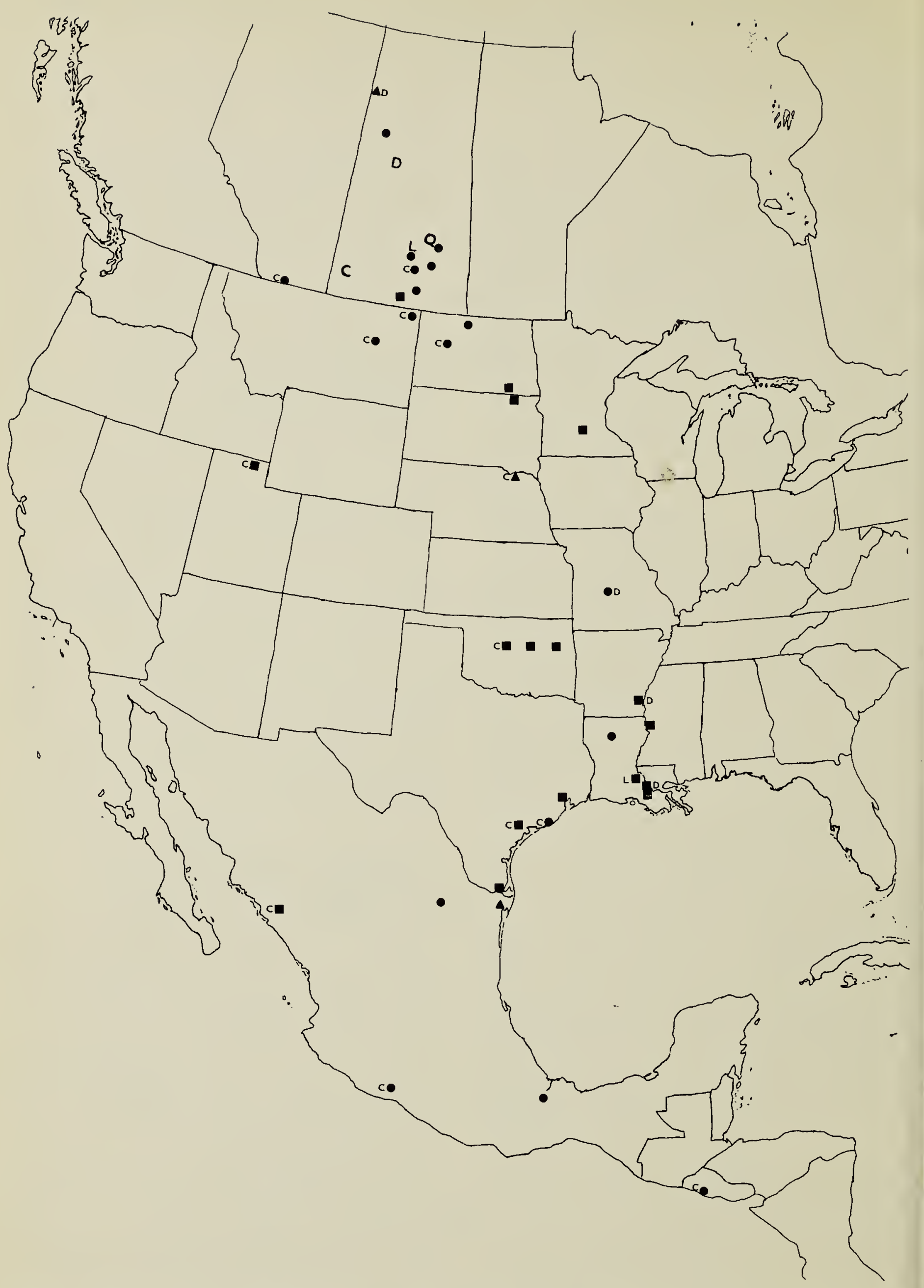

Fig. 2 Recoveries of White Pelicans banded by C. S. Houston at Last Mountain Lake (L), 1954; at Dore Lake (D), 1956; at Quill Lake (Q) 1956-58 and at Crane Lake (C) 1960-61. A letter beside each recovery indicates the lake of origin; those with no letter are from Quill Lake. Squares represent direct recoveries (same year); triangles, January 1 to June 30 of following year; circles, more than one year old. 
Table 1. Recoveries of Saskatchewan-banded White Pelicans.

\begin{tabular}{lllrrr}
\hline Bander & Lake & Years & Banded & Recov. & \% Recov. \\
\hline J. A. M. Patrick & Quill & $1930-32$ & 985 & 71 & $7.2 \%$ \\
Fred G. Bard & Quill & $1931-37$ & 325 & 34 & $10.5 \%$ \\
\multicolumn{1}{c}{ " } & Last Mountain & 1948 & 41 & 1 & $2.4 \%$ \\
Lyon \& McArthur & Old Wives & 1958 & 591 & 44 & $7.4 \%$ \\
Gresham \& Haak & Redberry & $1936-37$ & 328 & 36 & $11.0 \%$ \\
C. S. Houston & Last Mountain & 1939 & 21 & 3 & $14.3 \%$ \\
\multicolumn{1}{c}{$"$} & Dore & 1954 & 15 & 1 & $6.7 \%$ \\
\multicolumn{1}{c}{ " } & Quill & $1956-58$ & 395 & 20 & $5.7 \%$ \\
& Crane & $1960-61$ & 130 & 13 & $10.0 \%$ \\
& Redberry & $1955-64$ & 1258 & 82 & $6.5 \%$ \\
\hline
\end{tabular}

with previous years. This may indicate an increased reporting of birds found by citizens of Mexico, or wider dispersal of the birds, or both, but recent recoveries now give a complete coverage of the gulf shore from Florida all the way around the eastern coast of Mexico to Yucatan.

\section{LITERATURE CITED}

Behle, W. H. 1958. The bird life of Great Salt Lake. University of Utah Press, Salt Lake City.
Diem, K. L., and D. D. Condon. 1967. Banding studies of water birds on the Molly Islands Yellowstone Lake, Wyoming. Yellowstone Libraary and Museum Assn., Yellowstone National Park.

Houston, C. S. 1967. Saskatehewan bird banders: Judge J. A. M. Patrick (18731943). Blue Jay, $25: 172-174$.

Houston, C. S. 1968. Saskatchewan banders: William I. Lyon and H. E. McArthur. Blue Jay, $26: 185-187$.

Houston, C. S. 1970. Saskatchewan bird banders ; Fred G. Bard. Blue Jay. $28: 150-156$.

Houston C. S. 1971. Recent Saskatchewan banding of the Double-crested Cormorant. Blue Jay, $29: 74-79$.

\section{WINTER WREN, SPRAGUE'S PIPIT AND OTHER RECORDS AT CHURCHILL}

By Richard A. Forster, Massachusetts Audubon Society Lincoln, Massachusetts 01773

Summary accounts of Churchill birds by Jehl and Smith have recently been made available (Birds of the Churchill region, Manitoba. Manitoba Museum of Man \& Nature, Spec. Publ. No. 1, Winnipeg, 1970). Since their publication appeared, some significant records obtained by $R$. Pittaway and others were published in the June 1971 Blue Jay (29:60-63).

A few observations made at Churchill in 1971 by members of a Massachusetts Audubon Society tour and myself, including first reports of Winter Wren and Sprague's Pipit, seem worth recording.

Harlequin Duck

Histrionicus histrionicus

A drake was observed at Cape Merry on the evening of June 25, 1971.

This is the second record for the area, a male having been seen from July 11 to July 14,1970 at the same place by Pittaway and I. Newton (Blue Jay, 29:60).

\section{Yellow Rail}

\section{Coturnicops noveboracensis}

Heard calling at Landing Lake on June 24, 1971 and subsequently. This matches the first date of their occurrence recorded by Pittaway in 1970 (Blue Jay, 29:60).

Great Yellowlegs Tringa melanoleuca

Seven were found at the Goose Creek Road on June 23, 1971. The species was considered "accidental in spring" by Jehl and Smith (1970:40). Ring-billed Gull Larus delawarensis

A single bird was seen several times at the Fort Churchill dump from June 21-25, 1971. 